\title{
Expression of Specific Tubulin Isotypes Increases during Regeneration of Injured CNS Neurons, But Not after the Application of Brain-Derived Neurotrophic Factor (BDNF)
}

\author{
Alyson E. Fournier and Lisa McKerracher \\ Faculté de Médecine, Département de Pathologie, Université de Montréal, and McGill University, C.P. 6128, Succursale \\ Centre-ville Montréal, Québec H3C 3J7, Canada
}

\begin{abstract}
Axonal regrowth after injury is accompanied by changes in the expression of tubulin, but the contributions of substrate molecules and neurotrophic factors in regulating these changes in vivo are not known. Adult rat retinal ganglion cells (RGCs) were examined after intraorbital axotomy, after application of a peripheral nerve (PN) graft to stimulate regeneration, and after axotomy and treatment with brain-derived neurotrophic factor (BDNF). After these treatments we used in situ hybridization to study mRNA levels for $\beta \mathrm{l}, \beta \mathrm{ll}, \beta \mathrm{III}, \beta \mathrm{IV}$, and $\mathrm{T} \alpha 1$ tubulin isotypes. Levels of mRNA for all isotypes were downregulated after intraorbital axotomy. During regrowth of injured RGC axons, mRNA levels for $\beta \| l, \beta I I I$, and T $\alpha 1$ isotypes were upregulated specifically and dramatically, suggesting that elevated expression of these isotypes is correlated specifically with axonal regrowth. A corresponding increase in $\beta$ III protein levels
\end{abstract}

was detected by immunocytochemistry. The $\beta \mathrm{I}$ and $\beta \mathrm{IV} \mathrm{V}_{\mathrm{a}} \mathrm{mR}-$ NAs were not increased during regeneration. BDNF did not elicit a specific increase in the mRNA levels for the $\beta$ III and $T \alpha 1$ isotypes and had only a small effect on mRNA levels for the $\beta$ II isotype. Therefore, despite the ability of BDNF to support the survival of injured RGCs and to enhance neurite outgrowth of retinal neurons in vitro, the in vivo application of BDNF alone is unable to induce the program of changes in growth-associated tubulins that accompany regeneration of RGC axons into PN grafts. We speculate that, in addition to BDNF, cooperative signaling with substrate molecules is required to allow RGCs to regenerate and exhibit tubulin isotype switching.

Key words: BDNF; tubulin isotypes; microtubules; rat; regeneration; axotomy
Axonal injury of adult neurons results in a number of changes that are detectable in the cell body, including marked changes in the levels of various types of mRNAs. Changes in mRNA levels for cytoskeletal proteins are of interest because they are correlated tightly with neurite outgrowth, and cytoskeletal proteins support the regenerating axon and growth cone. Similarly, the factors that modify expression levels of these proteins may play critical roles in regeneration. Some cytoskeletal mRNAs show similar changes after axonal injury in the CNS and PNS, such as the decrease in mRNAs that encode neurofilaments (Hoffman and Cleveland, 1988; Tetzlaff et al., 1991; McKerracher et al., 1993a). However, the regulation of tubulin mRNAs after injury differs according to the neuronal cell type and the distance of axotomy from the cell body (for review, see Bisby and Tetzlaff, 1992; Tetzlaff et al., 1994). After axotomy in the CNS where there is no sustained regeneration, there is a long-term decrease in total tubulin $\mathrm{mR}$ NAs, but sometimes an early transient increase in tubulin mRNAs occurs (Tetzlaff et al., 1991; McKerracher et al., 1993b). In the PNS an overall increase in total tubulin mRNA is observed after peripheral nerve injury when neurons regenerate spontaneously; this is attributable to increases in specific tubulin isotype mRNAs.

\footnotetext{
Received Dec. 18, 1996; revised Feb. 14, 1997; accepted April 2, 1997.

We gratefully acknowledge support from Natural Science and Engineering Research Council of Canada. L.M. is supported by Fonds de la Recherche en Santé du Québec and A.E.F. holds an Fonds pour la Formations de Chercheurs et l'Aide à la Recherche student scholarship. We thank Yi-Chun Wang and Soran Singel for surgical assistance and Gaston Lambert for help with the figures.

Correspondence should be addressed to Dr. Alyson Fournier, Faculté de Médecine, Département de Pathologie, Université de Montréal, C.P. 6128, Succursale Centre-ville, Montréal, Québec H3C 3J7, Canada.

Copyright (C) 1997 Society for Neuroscience $0270-6474 / 97 / 174623-\bullet \$ 05.00 / 0$
}

Isotypes are distinct members of the large tubulin gene family that encode both $\alpha$ and $\beta$ tubulin subunits, and these isotypes are regulated differentially during development (Lewis et al., 1985; Jiang and Oblinger, 1992). The $\beta$ II, $\beta$ III, and T $\alpha 1$ isotype levels are elevated after peripheral nerve injury, whereas $\beta \mathrm{I}, \beta \mathrm{IV}$, and T26 levels are not (Miller et al., 1987, 1989; Hoffman and Cleveland, 1988; Tetzlaff et al., 1991; Moskowitz et al., 1993). It is not known if the different tubulin isotypes are affected differentially by injury and during regeneration in the CNS as they are in peripheral nerves.

It also is not known if tubulin expression in injured neurons may be affected by the presence of neurotrophic factors present in the non-neuronal extracellular environment after injury. An understanding of the different factors that regulate the complex changes in tubulin will be important to our understanding of the regenerative process. Examination of adult rat retinal ganglion cells (RGCs) has helped to identify a number of extrinsic signals important for regrowth of injured axons. Brain-derived neurotrophic factor (BDNF), a major neurotrophic factor for RGCs, is able to augment RGC survival (Mey and Thanos, 1993; MansourRobaey et al., 1994) and influence neurite outgrowth in cell culture (Johnson et al., 1986; Rodriguez-Tebar et al., 1989; Thanos et al., 1989; Cohen et al., 1994). Furthermore, BDNF is produced by Schwann cells that are present in PN grafts, which can support regeneration of some injured RGCs (David and Aguayo, 1981). Although the in vivo application of BDNF in the eye does not enhance the number of RGC axons able to penetrate peripheral nerve (PN) grafts (Mansour-Robaey et al., 1994), it is not clear if this is attributable to a failure of BDNF to stimulate regeneration-associated changes in gene expression or attribut- 
able to blocked neurite outgrowth because of inhibitory molecules present at the optic nerve head. We sought to test directly the effect of BDNF on intrinsic determinants of regeneration in RGCs by following changes in mRNA levels for some growthassociated tubulin genes in response to BDNF.

\section{A. Normal optic nerve}

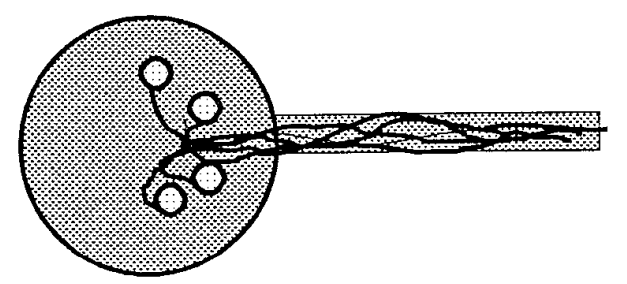

\section{B. Axotomy}

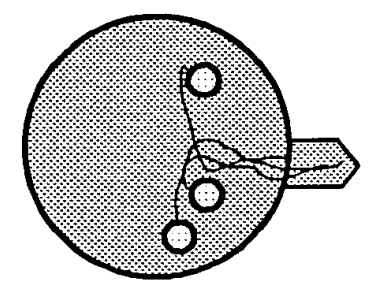

C. Axotomy + PN graft

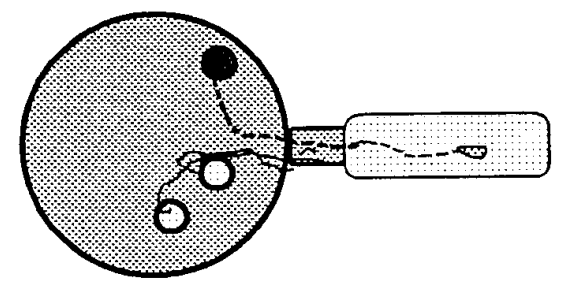

D. Axotomy + BDNF

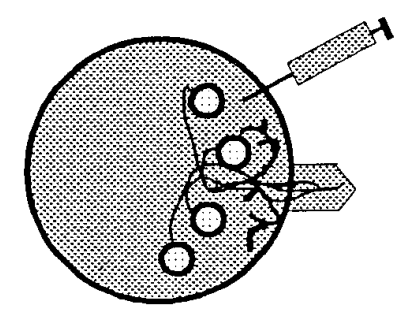

Figure 1. Schematic representation of the surgical procedures and the known morphological response of injured retinal ganglion cells. $A$, Normal adult rat retinal ganglion cells project their axons into the optic nerve. $B$, After axotomy some RGCs die (Villegas-Perez et al., 1993), and RGC axons retract into the optic nerve head. $C$, Application of a peripheral nerve graft to injured RGCs elicits long distance regrowth of a small number of RGCs (a regenerating RGC is shown in black) (Vidal-Sanz et al., 1987). D, A single application of BDNF prevents all death (MansourRobaey et al., 1994), and there is an increase in axonal branch length (Sawai et al., 1996).

By following mRNA levels in regenerating RGCs identified by retrograde labeling, we document here that the $\beta \mathrm{II}, \beta \mathrm{III}$, and T $\alpha 1$ isotypes are upregulated specifically only in those RGCs that successfully regrow their axons. Elevation of these mRNAs therefore specifically correlates with regrowth of injured RGCs in vivo. We also document that BDNF was not sufficient by itself to induce changes in tubulin mRNA levels.

\section{MATERIALS AND METHODS}

Surgical procedure and BDNF applications. Adult female Sprague Dawley rats $(180-220 \mathrm{gm})$ were anesthetized with chloral hydrate $(0.42$ $\mathrm{mg} / \mathrm{gm}$ body weight, i.p.), and the left optic nerve was exposed and transected $0.5 \mathrm{~mm}$ from the optic nerve head (Fig. $1 b$; Villegas-Perez et al., 1993). For sham operations the left optic nerve was exposed but not cut. To graft a peripheral nerve to the optic nerve stump, we attached an autologous segment of sciatic nerve with 10.0 sutures (Fig. 1c; Vidal-Sanz et al., 1987). Crystals of the retrograde tracer DiI (VidalSanz et al., 1988) were inserted at multiple sites along the length of the graft before closing the skin with silk sutures. BDNF-treated animals had their left eye injected with $5 \mu \mathrm{g}$ of BDNF in $5 \mu \mathrm{l}$ of PBS, $0.5 \%$ BSA immediately after optic nerve cut (Fig. 1d). A posterior approach for injection was used because the local release of endogenous factors into the eye is minimized, as compared with an anterior approach (Mansour-Robaey et al., 1994). For injection the eye was rotated forward, the sclera was punctured with a 26 gauge needle, and BDNF was injected with a Hamilton syringe. For controls, the vehicle of $5 \mu \mathrm{l}$ of PBS, $0.5 \%$ BSA was injected (called PBS treatment). Rats were killed $3 \mathrm{~d}(n=4)$ or $14 \mathrm{~d}(n=4)$ after axotomy and $14 \mathrm{~d}$ after sham axotomy $(n=2)$. Animals with a PN graft $(n=3)$ were examined from 14 to $20 \mathrm{~d}$ after grafting, a time when RGC axons are growing actively along the graft (McKerracher et al., 1990). Animals that received axotomy and BDNF treatment were examined at $3 \mathrm{~d}(n=3)$ and $14 \mathrm{~d}$ $(n=4)$. Animals treated by axotomy and PBS injections were processed at $3 \mathrm{~d}(n=3)$ and $14 \mathrm{~d}(n=2)$. These times were chosen because BDNF has maximal effects on gene expression $3 \mathrm{~d}$ after injection into the eye (Fournier et al., 1997), whereas $14 \mathrm{~d}$ is a time when axotomy alone is known to affect gene expression and is also appropriate for detecting regenerating RGCs in PN-grafted animals (McKerracher et al., 1990).

When the animals were killed, their eyes were removed and immersionfixed in $4 \%$ paraformaldehyde and $0.1 \mathrm{~m}$ phosphate buffer, $\mathrm{pH} 7.2$, for 3-4 hr. The lens and cornea were removed, and the eyes were placed in an RNase-free solution of $10 \%$ sucrose in PBS overnight. Left and right eyes were mounted and frozen together in Tissue Tek O.C.T. (Canlab, Montreal, Quebec). The blocks were stored at $-80^{\circ} \mathrm{C}$ until cryostat sections of $8-12 \mu \mathrm{m}$ were cut. Multiple slides were examined for each animal ( $n=3-10$ slides, typically 5 slides).

Preparation of RNA and Northern blots. Total RNA was prepared from postnatal day 1 (P1) rat brain, adult brain, and retina. For the retinal samples six retinas from three animals were pooled before homogenization and prepared by the acid phenol method (Chomczynski and Sacchi, 1987). Total RNA was separated electrophoretically on formaldehyde gels and transferred to Nytran filters. Equal amounts of RNA were

B1

P1 Ad R
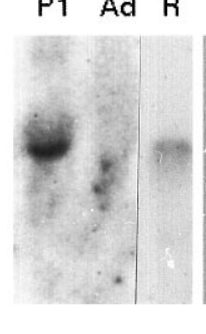

Figure 2. Northern blots of postnatal day $1(P 1)$ rat brain, adult rat brain $(A d)$, and adult rat retina $(R)$. Blots were probed with ${ }^{32} \mathrm{P}$-labeled cDNA antisense probes recognizing the $\beta I, \beta I I, \beta I I I$, and $\beta I V_{\mathrm{a}}$ tubulin isotypes. The $\beta I, \beta I I$, and $\beta I I I$ isotype mRNA levels were highest in the developing rat brain, whereas the $\beta I V_{\mathrm{a}}$ isotype mRNA was highest in the adult. The mRNAs for all isotypes were detected in the adult rat retina. 

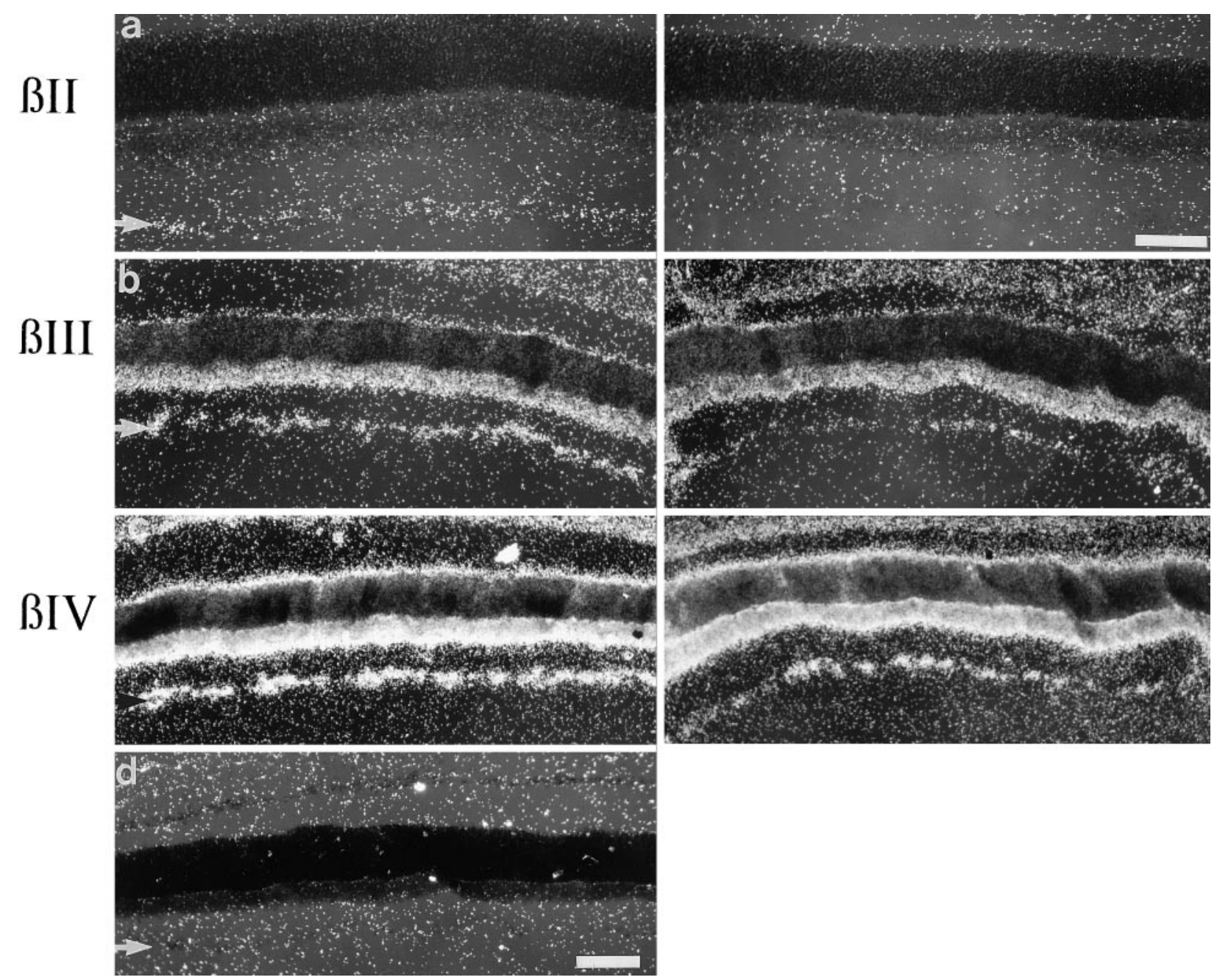

Figure 3. $\beta$-Tubulin isotype mRNA levels decrease after axotomy. Dark-field micrographs of radial sections from uninjured contralateral control (left panel) or 2 week axotomized (right panel) retinas probed with ${ }^{35}$ S-labeled cRNA probes recognizing the $\beta$ II $(a), \beta \operatorname{III}(b)$, and $\beta$ IV ${ }_{\mathrm{a}}(c)$ isotypes. All isotype mRNA levels were reduced 2 weeks after injury. $d$, Dark-field micrograph of a radial retinal section probed with a control $\beta$ II sense probe. Scale bar $(a)$, $85 \mu \mathrm{m} ;(b-d), 100 \mu \mathrm{m}$. The retinal ganglion cell layer is indicated in each micrograph in the left panel by an arrow.

loaded in each lane, and this was verified by ethidium bromide staining of formaldehyde gels. Probes of $\sim 300$ base pairs in length and recognizing the unique $3^{\prime}$ regions of the $\beta \mathrm{I}, \beta \mathrm{II}, \beta \mathrm{III}$, and $\beta \mathrm{IV}_{\mathrm{a}} \beta$-tubulin isotypes were generated by oligolabeling with ${ }^{32} \mathrm{P}$-dCTP (Pharmacia, Montreal, Quebec). The mouse $\beta$-tubulin cDNAs were obtained from Dr. Nicholas Cowan (New York University Medical Center, New York). The T $\alpha 1$ probe was 174 base pairs and was derived from a pGEM-4 plasmid provided by Dr. Freda Miller (McGill University, Montreal) (Miller et al., 1987). For this, the T $\alpha 1$ cDNA was linearized with HindIII before in vitro transcription with SP6 polymerase. Sense probes were generated by linearizing with EcoRI and by using T7 polymerase.

Blots were prehybridized for $1 \mathrm{hr}$ with $2 \times \mathrm{SSC}, 50 \%$ deionized formamide, $1 \mathrm{~mm}$ DTT, $250 \mu \mathrm{g} / \mathrm{ml}$ denatured tRNA, $250 \mu \mathrm{g} / \mathrm{ml}$ denatured fish sperm DNA, $1 \times$ Denhardt's solution, 5 mM EDTA, pH 8, and $0.2 \%$ SDS and then hybridized overnight. Washes were in $4 \times$ SSC, $0.1 \%$ SDS for $2 \times 30 \mathrm{~min}$ and then $2 \times$ SSC, $0.1 \%$ SDS for $2 \times 30 \mathrm{~min}$. Hybridization and washing were at $45^{\circ} \mathrm{C}$ for cDNA probes or $65^{\circ} \mathrm{C}$ for cRNA probes. Blots were exposed to autoradiographic film and were stripped and reprobed up to five times.

In situ hybridization. Slides were removed from $-80^{\circ} \mathrm{C}$ and warmed on a slide warmer; sections from grafted animals were examined under the fluorescence microscope to identify and document the position of DiIlabeled cells. For in situ hybridization slides were acetylated, washed in PBS, and pre-hybridized as for Northern blots for $1 \mathrm{hr}$ at $42^{\circ} \mathrm{C}$. Slides subsequently were hybridized overnight at $42^{\circ} \mathrm{C}$ with $1 \times 10^{6} \mathrm{cpm}$ of labeled probe per two pairs of retinal sections. ${ }^{35}$ S-labeled $\beta$-tubulin cDNA and T $\alpha 1$ cRNA probes were generated as described for Northern blots and used in preliminary experiments. To increase sensitivity for in situ hybridization, we subcloned $\beta \mathrm{II}, \beta \mathrm{III}$, and $\beta \mathrm{IV}_{\mathrm{a}}$ isotypes into the EcoRI/HindIII site of pGEM $72^{+}$vectors to generate cRNA probes by in vitro transcription. Antisense and sense probes were generated from linearized plasmids and transcription from the SP6 or T7 promoter as appropriate. After hybridization, slides were washed sequentially in $4 \times$ SSC, $1 \mathrm{~mm}$ DTT for $2 \times 10 \mathrm{~min}$ and $4 \times \mathrm{SSC}$ for $2 \times 10 \mathrm{~min}$ at $65^{\circ} \mathrm{C}$ for cRNA probes and $45^{\circ} \mathrm{C}$ for cDNA probes. For cRNA probes singlestranded RNA was digested with RNase A $(50 \mu \mathrm{g} / \mathrm{ml}$ RNase A, $0.5 \mathrm{M}$ $\mathrm{NaCl}, 10 \mathrm{~mm}$ Tris, and $0.1 \mathrm{~mm}$ EDTA) at $37^{\circ} \mathrm{C}$ for $30 \mathrm{~min}$. Final washes were with SSC, gradually increasing the stringency to a final wash of $0.1 \times$ SSC for $20 \mathrm{~min}$ at $65^{\circ} \mathrm{C}$ for cRNA probes and $45^{\circ} \mathrm{C}$ for cDNA probes. The same hybridization patterns were observed with cDNA and cRNA probes for a given isotype. The cRNA probes were used for experiments with quantitative analysis because of a cleaner hybridization signal.

Emulsion autoradiography and quantitative analysis. After in situ hybridization slides were air-dried and dipped in Kodak NTB2 autoradiographic emulsion diluted 1:1 with water and stored in a light-tight box. Exposure times for the tubulin probes varied from 2-4 weeks. Slides were developed for 5 min in Kodak D19 mixed 1:1 with water at $20^{\circ} \mathrm{C}$, rinsed, and fixed for $5 \mathrm{~min}$ in Kodak fix. Sections were stained with $0.25 \%$ thionin stain and permanently mounted in Entellan (VWR, Canada).

An Image 1 (Universal Imaging, West Chester, PA) image analysis system was used to count the number of autoradiographic silver grains over RGCs of treated and intact retinas after in situ hybridization. Treated and control sections were cut together and thus were hybrid- 


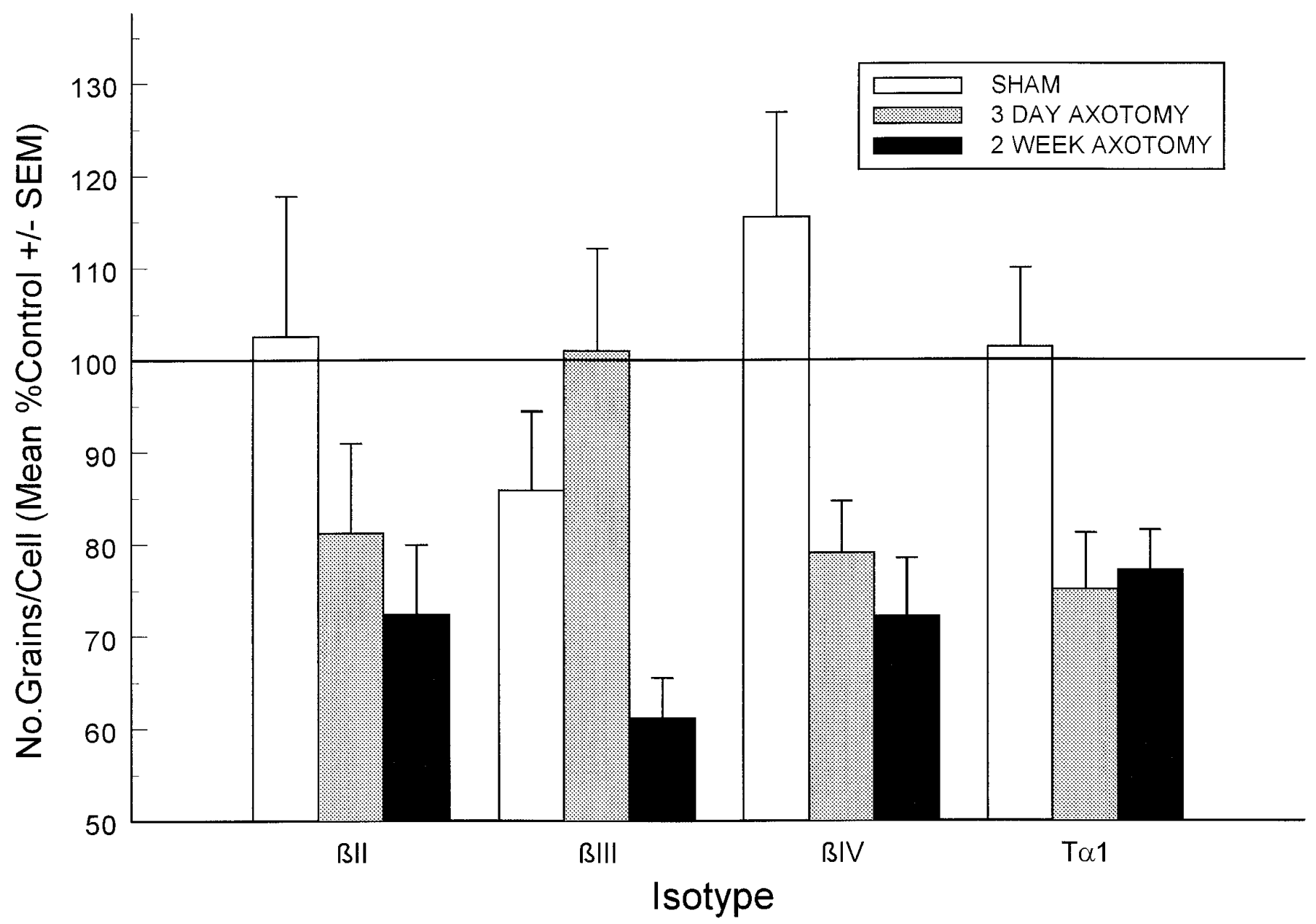

Figure 4. Quantitative analysis of tubulin isotype mRNA levels $3 \mathrm{~d}$ and 2 weeks after intraorbital axotomy. Counts from the experimental retinas were compared with the contralateral retinas mounted on the same slide, and the contralateral control was expressed as 100\%. Each bar represents data from multiple slides from multiple animals (see Materials and Methods). The $\beta I I, \beta I V_{\mathrm{a}}$, and $T \alpha 1$ levels decreased by $3 \mathrm{~d}$ after injury and remained low at 2 weeks. The $\beta I I I$ isotype levels decreased by 2 weeks after injury. Sham-operated rats did not show significant changes.

ized and dipped in emulsion on the same slide. This control for experimental variability allowed for remarkably consistent results when the average number of grains per RGC was determined and expressed as a percentage of that in the same slide control retina. Cells smaller than $70 \mu \mathrm{m}$, which would include all of the displaced amacrine cells, were excluded from the analysis. Also, cells larger than $130 \mu \mathrm{m}$, which rarely were observed, were excluded from the analysis. Hybridization "hotspots" were identified visually, and quantitation was performed. Occasionally, hotspots that did not correlate with DiI-labeled cells were identified most likely because the regenerating RGC failed to take up or retrogradely transport DiI from the graft. Statistics were performed with the Sigma Stat statistical program (Jandel, Corte Madera, CA). Data that met the criteria for parametric tests were analyzed by a Student's $t$ test. Groups of data that failed tests for normality were analyzed by the Mann-Whitney test.

Immunocytochemistry. Tissue was prepared as described for in situ hybridization. DiI back-labeled cells were identified by fluorescence microscopy, and their positions were documented. Then slides were washed in PBS and blocked for $1 \mathrm{hr}$ at room temperature in 3\% BSA, $0.1 \%$ Triton X-100 in sterile PBS. Slides were incubated overnight at room temperature with the primary antibody. The monoclonal anti- $\beta$ tubulin isotype I and II antibody (Sigma, St. Louis, MO) was used at a dilution of 1:1000. The monoclonal anti- $\beta$ III antibody (Sigma) was used at 1:200. Slides were incubated with goat anti-mouse IgG FITC antibody (Calbiochem, San Diego, CA) in PBS, used at a 1:100 dilution. Slides were washed in PBS and mounted in SlowFade (Molecular Probes, Eugene, OR).

\section{RESULTS}

\section{Each tubulin isotype mRNA decreases after axotomy}

Four different $\beta$-tubulin isotypes and two $\alpha$-tubulin isotypes are expressed in rodent brain with a distinctive developmental profile (Lewis et al., 1985; Miller et al., 1987). To determine which isotypes are expressed in adult rat retina and to confirm that the mouse $\beta$-tubulin isotypes are found in rat brain, we prepared Northern blots with RNA extracted from P1 brain, adult brain, and adult retina. Each of the four $\beta$-tubulin isotypes recognized distinct bands of the predicted sizes (Fig. 2). The $\beta \mathrm{I}, \beta \mathrm{II}$, and $\beta \mathrm{III}$ isotypes were expressed at higher levels in P1 brain than in adult brain, and the $\beta \mathrm{IV}_{\mathrm{a}}$ isotype showed a reciprocal pattern of expression, with the highest levels in adult brain. These results, which are consistent with previous reports (Lewis et al., 1985; Jiang and Oblinger, 1992) show that the $\beta$-tubulin isotypes are regulated differentially during rat brain development. Further, $\beta \mathrm{I}$, $\beta \mathrm{II}, \beta \mathrm{III}$, and $\beta \mathrm{IV}_{\mathrm{a}}$ isotypes were each detected in the adult rat retina (Fig. 2). The rat T $\alpha 1 \alpha$-tubulin isotype also has been characterized fully. T $\alpha 1$ is a neuron-specific isotype expressed at high levels in developing rat brain and in regenerating peripheral neurons (Miller et al., 1987, 1989). In previous in situ hybridiza- 

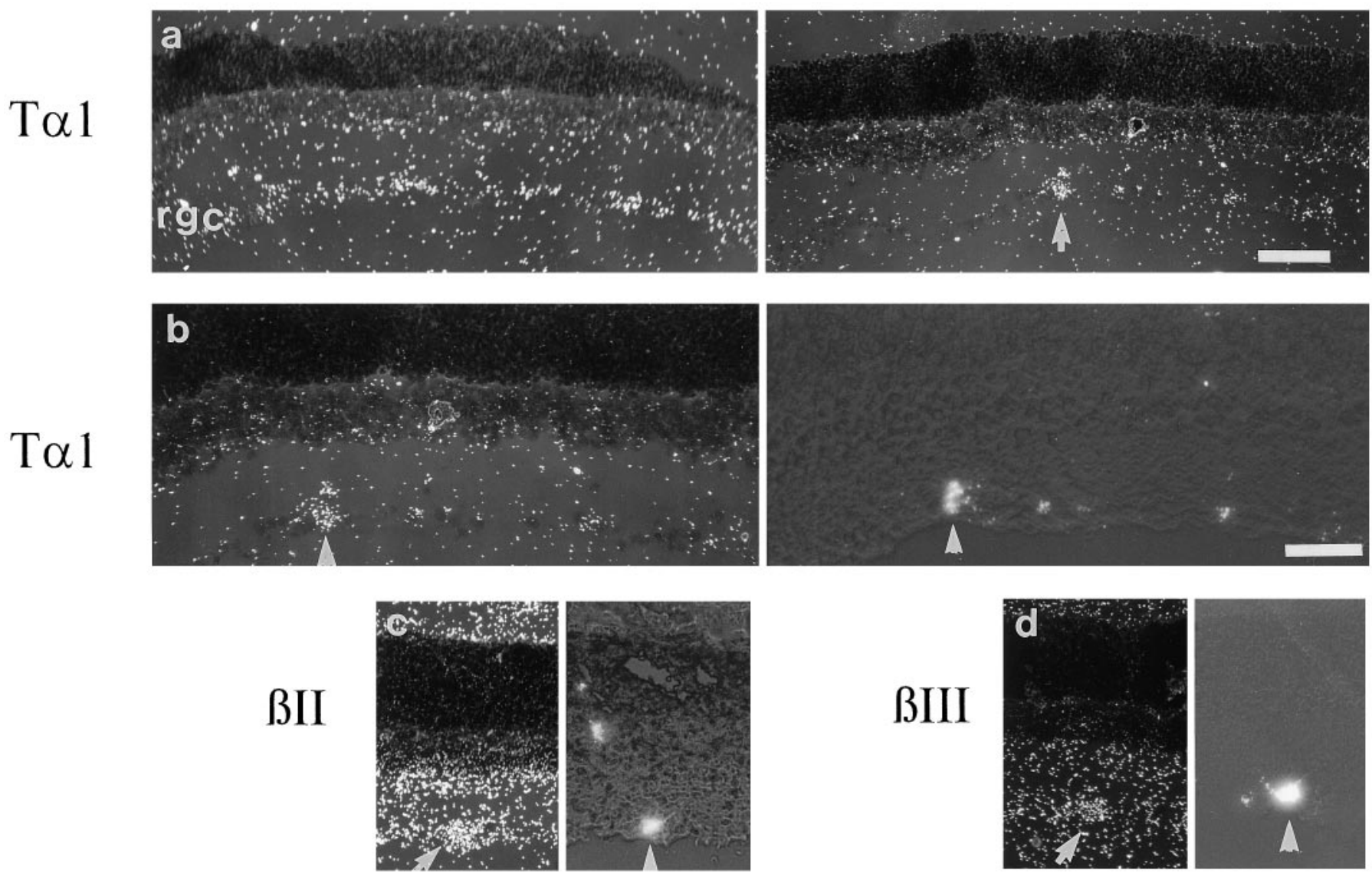

Figure 5. $\beta \mathrm{II}, \beta \mathrm{III}$, and T $\alpha 1$ mRNA levels are upregulated specifically in regenerating RGCs. $a$, Dark-field micrographs of radial sections from an uninjured contralateral control retina $(a$, left panel $)$ and a retina 2 weeks after injury and peripheral nerve graft application $(a$, right panel $)$. Retinas were probed with a T $\alpha 1$ antisense probe. T $\alpha 1$ mRNA levels were decreased in most RGCs but were upregulated specifically in a small number of RGCs (arrow). $b-d$, Radial retinal sections visualized by fluorescence microscopy (right panel) showing RGCs that have been retrogradely labeled with DiI (arrowheads). The left panel shows the same section after in situ hybridization with T $\alpha 1, \beta \mathrm{II}$, or $\beta \mathrm{III}$ antisense probes. $\beta \mathrm{II}, \beta \mathrm{III}$, and T $\alpha 1$ mRNA levels were enhanced specifically in regenerating RGCs that had taken up the DiI marker. Scale bars: in $a, 85 \mu \mathrm{m}$; in $b-d, 55 \mu \mathrm{m}$. rgc, Retinal ganglion cell layer.

tion studies of the retina, we have documented that T $\alpha 1$ (Fournier et al., 1997) and $\beta \mathrm{I}$ (Fournier and McKerracher, 1995) isotypes are expressed in the retina, and the individual $\beta$-tubulin isotypes studied here, $\beta \mathrm{II}, \beta \mathrm{III}$, and $\beta \mathrm{IV}_{\mathrm{a}}$, all showed similar patterns of expression in the different retinal layers (Fig. 3). Therefore, many types of adult retinal neurons express at least four different $\beta$-tubulin mRNAs (Fournier and McKerracher, 1995). With sense probes used as controls, only very light labeling was distributed equally over all layers (Fig. $3 d$ ).

After intraorbital transection of the optic nerve (Fig. 1), the hybridization signal for each isotype decreased in the RGC layer of the retina (Fig. 3). Such a change was not observed in the other cellular layers that were not influenced directly by the optic nerve cut. It is known that RGCs begin to die $3 \mathrm{~d}$ after axotomy and that by 2 weeks only $12 \%$ of RGCs survive (Villegas-Perez et al., 1993). To determine whether the loss in the hybridization signal resulted exclusively from cell death or whether changes in the mRNA levels in the surviving RGCs contributed to the loss of signal, we counted the grains over individual cells to estimate relative mRNA levels, as compared with contralateral controls processed on the same slide. This analysis demonstrated that the mRNA levels decreased in the individual cells. The grain counts for the $\beta \mathrm{II}, \beta \mathrm{IV}_{\mathrm{a}}$, and $\mathrm{T} \alpha 1$ isotypes were decreased to 81,79 , and $75 \%$ of control levels, respectively, $3 \mathrm{~d}$ after axotomy. The $\beta \mathrm{III}$ isotype was more resistant to this downregulation, and its mRNA level was maintained at $100 \%$ of control levels at this early time (Fig. 4). However, by $14 \mathrm{~d}$ there was a drop in the signal for this isotype to $61 \%$ of the control level, and the mRNA levels for all of the other isotypes remained low, as compared with controls or with sham-operated animals (Fig. 4). At 2 weeks the $\beta \mathrm{II}, \beta \mathrm{IV}_{\mathrm{a}}$, and T $\alpha 1$ mRNA levels were 72,72 , and $77 \%$ of contralateral control levels, respectively. Decreased expression levels for the $\beta \mathrm{III}, \beta \mathrm{IV}_{\mathrm{a}}$, and T $\alpha 1$ isotypes were significant 2 weeks after axotomy. Decreases in $\beta \mathrm{III}$ and $\beta \mathrm{IV}_{\mathrm{a}}$ were analyzed by the Student's $t$ test, whereas the decrease in T $\alpha 1$ was analyzed by the MannWhitney test. Therefore, in contrast to responses in injured peripheral nerves where isotype-specific changes are induced, RGC injury results in a similar change in mRNA levels for all tubulin isotypes.

\section{Specific tubulins mRNAs are elevated in regenerating RGCs}

We next investigated how a peripheral nerve graft might modify the drop in tubulin isotype levels after axotomy. For these experiments RGCs that regenerated their axons were detected by retrograde labeling with DiI. DiI was applied to the peripheral nerve graft at the time of grafting, and regenerating RGC axons took up the tracer as they grew in the PN graft and transported it 


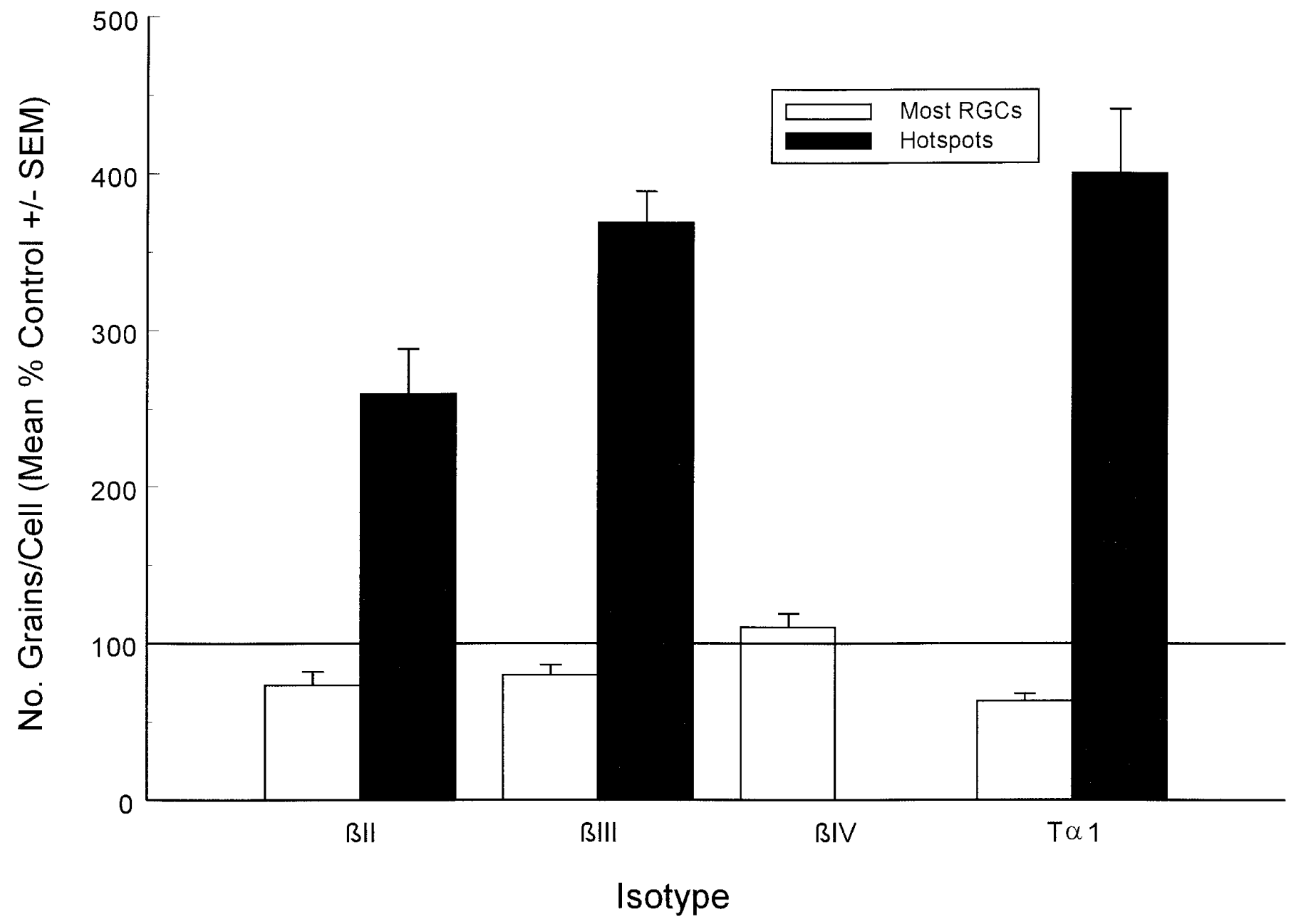

Figure 6. Quantitative analysis of isotype mRNA levels in regenerating and nonregenerating RGCs 2 weeks after injury and peripheral nerve graft application. The $\beta I I$, $\beta I I I$, and $T \alpha 1$ mRNA levels were decreased in most RGCs but were enhanced dramatically in some RGCs. The $\beta I$ and $\beta I V$ isotypes were not increased in RGCs in PN-grafted retinas.

back to the cell body. Then the mRNA levels were examined in RGCs with and without DiI labeling. The RGCs were examined 14-20 d after surgery, times when some RGCs have extended axons in the graft (McKerracher et al., 1990). After axotomy with a PN graft attached to the optic nerve stump, hybridization of the retina with isotype-specific probes revealed that most RGCs had reduced mRNA levels for each of the separate isotypes, as was observed $14 \mathrm{~d}$ after axotomy alone (Fig. 5). However, dramatically enhanced mRNA levels were detected in a few RGCs in sections hybridized with the $\beta$ II (Fig. $5 c$ ), $\beta$ III (Fig. $5 d$ ), and T $\alpha 1$ (Fig. $5 a, b)$ isotype probes. These RGC "hotspots" were not observed after hybridization with probes for the $\beta \mathrm{I}$ or $\beta \mathrm{IV}_{\mathrm{a}}$ isotypes. Further examination revealed that the hybridization hotspots correlated with the DiI back-labeled RGCs (Fig. $5 b-d$ ). Therefore, the $\mathrm{T} \alpha 1$ isotype and two of the three $\beta$-tubulin isotypes, the expression levels of which are high during development, are upregulated specifically in those RGCs that regenerated their axons into the PN grafts. Quantitative analysis of RGCs in the PN-grafted samples revealed that most RGCs decreased their mRNA levels for all isotypes, a result that correlates with the fact that a majority of RGCs do not regenerate in PN-grafted retinas. Only $\sim 3 \%$ of RGCs regenerate (Vidal-Sanz et al., 1987), and those RGCs that do not regrow do not increase their tubulin levels. Isotype mRNA levels were 73,80 , and $63 \%$ of control levels for the $\beta$ II, $\beta$ III, and T $\alpha 1$ isotypes, respectively (Fig. 6). These results are similar to those retinas that received an axotomy without a PN graft. Only $\beta \mathrm{IV}_{\mathrm{a}}$ tubulin levels were rescued by the graft, with average levels of $110 \%$ relative to intact contralateral controls. However, no hybridization hotspots were detected with the $\beta \mathrm{IV}_{\mathrm{a}}$ isotype probe. For the $\beta \mathrm{II}, \beta \mathrm{III}$, and T $\alpha 1$ isotypes mRNA levels in RGCs that appeared as hotspots increased dramatically over the control values. Grain counts of visually identified hotspots were 260, 369, and $401 \%$ of the control levels for the $\beta \mathrm{II}, \beta \mathrm{III}$, and T $\alpha 1$ isotypes, respectively (Fig. 6). All increases were statistically significant (Student's $t$ test).

To determine whether the increases in mRNA levels were indicative of changes in the level of tubulin protein, we used isotype-specific antibodies to immunolabel the sections. Such examination revealed that the DiI back-labeled cells tended to be stained more intensely with the anti- $\beta$ III $\beta$-tubulin antibody (Fig. 7). Normal retinal sections typically were well stained with the anti- $\beta \mathrm{I} / \beta \mathrm{II}$ antibody, but in some cases a correlation between high immunofluorescence and a DiI back-labeled cell could be detected. Failure to detect intensely immunopositive regenerating RGCs likely was attributable to high levels of expression of $\beta \mathrm{I}$ and $\beta$ II tubulin isotypes in adjacent injured 

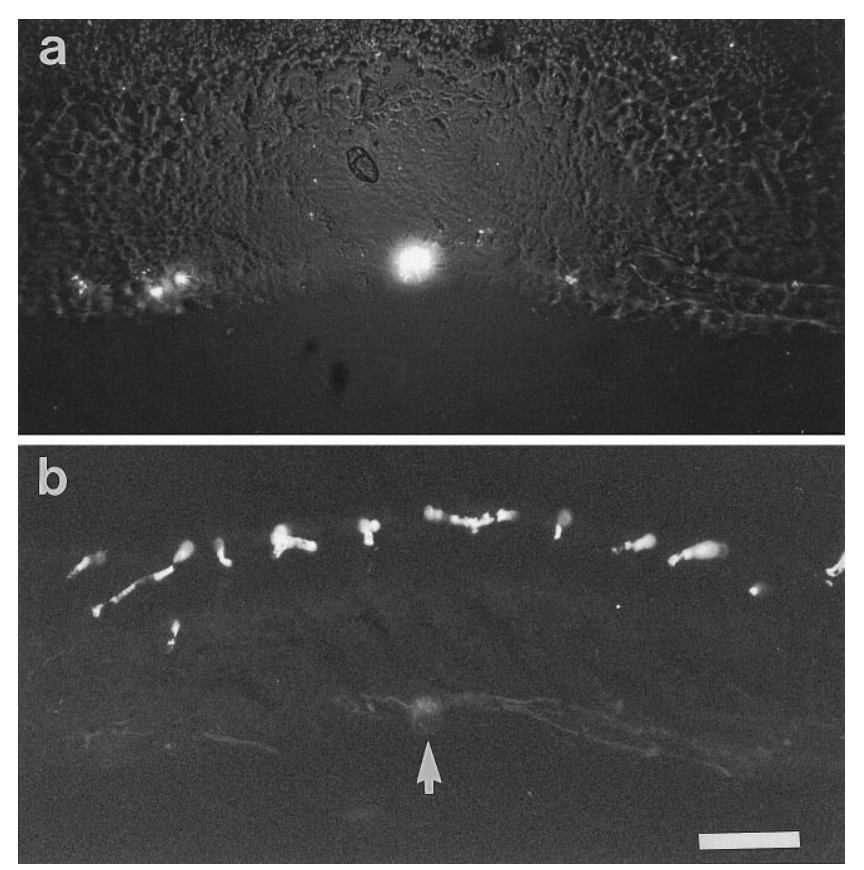

Figure 7. The $\beta$ III protein levels are enhanced specifically in regenerating RGCs (arrow). A radial retinal section visualized by fluorescence microscopy shows a retrogradely labeled RGC with DiI from a PN graft (a). The same RGC is labeled with FITC after immunocytochemistry with an anti- $\beta$ III antibody $(b)$. Note that the adjacent axotomized RGCs that do not extend axons in the graft (and are not labeled with DiI) are not immunoreactive. Immunolabeling with the $\beta \mathrm{III}$ antibody also was observed in the outer nuclear layer. Scale bar, $55 \mu \mathrm{m}$.

RGCs. Specific $\beta$ I and $\beta$ IV antibodies were not available at the time of these experiments.

\section{Application of BDNF fails to elicit marked changes in tubulin expression in injured RGCs}

BDNF is a potent survival factor for injured RGCs (MansourRobaey et al., 1994), and studies examining the effect of BDNF on GAP-43 expression indicate that most, if not all, RGCs respond to BDNF (Fournier et al., 1997). To examine if BDNF would modify the expression of the tubulin isotypes in injured RGCs, we injected BDNF into the vitreous of the eye at the time of axotomy. As a control, vehicle alone was injected into the eye. It is known that intraretinal injections of vehicle alone can enhance cell survival; however, this effect is minimal after posterior injections (Mansour-Robaey et al., 1994). Similarly, in this study we used a posterior approach and detected small changes in the PBS injection controls, because there was no decrease in the $\beta \mathrm{II}, \beta \mathrm{IV}_{\mathrm{a}}$, and T $\alpha 1$ mRNA levels $3 \mathrm{~d}$ after axotomy and PBS injection, as was observed with axotomy alone. Therefore, the control posterior injections exerted small but detectable effects on RGCs.

BDNF injection at the time of axotomy did not result in any general, dramatic changes in tubulin expression (Fig. 8). Three days after BDNF injection, a time when BDNF application has maximal effects on the expression of another growth-associated protein, GAP-43 (Fournier et al., 1997), only $\beta$ II isotype mRNA levels were increased significantly. Moreover, this increase to $122 \%$ of the intact contralateral level was modest, as compared with the changes observed when RGCs regenerated their axons in a peripheral nerve graft (Figs. 6, 8). BDNF injection had no significant effects on any of the other isotypes when compared with control PBS injections.
By 2 weeks after BDNF treatment, all of the tubulin isotypes dropped below the intact contralateral control levels (Fig. 8). The small effect of BDNF on $\beta$ II tubulin $3 \mathrm{~d}$ after axotomy was not sustained at 2 weeks.

\section{DISCUSSION}

\section{Tubulin isotypes are regulated differentially during RGC regeneration}

We have followed the expression of five tubulin isotypes in adult rat RGCs after injury, after injury and BDNF treatment, or after replacement of the optic nerve with a peripheral nerve graft. We have documented that each of these isotypes is expressed in adult rat RGCs. We find that mRNA levels for all isotypes are decreased in a similar manner after intraorbital RGC injury. Therefore, in contrast to neurons in the peripheral nervous system, RGCs do not spontaneously upregulate expression of growthassociated tubulin isotypes after injury close to the eye. We further demonstrate that long distance regrowth of injured RGCs is accompanied by a specific increase in the mRNA levels of the $\mathrm{T} \alpha 1, \beta \mathrm{II}$, and $\beta \mathrm{III}$ isotypes. Unlike other growth-associated proteins, such as GAP-43, the expression of which can be induced by injury alone in the CNS (Doster et al., 1991; Fournier et al., 1997), the expression of these tubulin isotypes is correlated tightly with long distance growth of RGC axons (Fig. 1c). The expression of $\mathrm{T} \alpha 1$ is upregulated after injury of rubrospinal neurons (Tetzlaff et al., 1991), but the morphological correlate of this response is unclear. The expression of all neuronal tubulin isotypes by RGCs, including the growth-associated isotypes, may allow for some local growth or plasticity in adult animals, but increased amounts of specific isotypes may be required to sustain regeneration of injured axons.

\section{BDNF enhances early regenerative events but does not mediate long distance growth in vivo}

It is known that BDNF stimulates intraretinal branching events of some injured RGCs (Sawai et al., 1996) and that the expression of GAP-43 is upregulated during these early events (Fournier et al., 1997). However, we have documented here that expression of the $\beta$ III and T $\alpha 1$ growth-associated tubulin isotypes is not affected dramatically by BDNF application, and only small effects on the $\beta$ II isotype were observed (Fig. 8). The inability of BDNF to enhance the expression of these isotypes suggests that BDNF alone does not stimulate molecular events required for long distance axon growth because increases in these mRNAs correlated with the regeneration of RGC axons into PN grafts. If BDNF alone does not stimulate all the changes in gene expression that correlate with regeneration, additional factors in the PN graft, such as substrate cues, may be critical for successful regeneration. Although it is possible that the intravitreal injection of BDNF did not mimic the effects of a PN graft because it was not applied at the cut axon stump, we do not think this is the case. First, after intraorbital axotomy most RGC axons retract into the eye where they should have adequate access to the exogenously applied BDNF. Furthermore, BDNF applied to the vitreous increases the axonal branch length of injured RGCs, a finding that indicates that injured RGC axons do respond to BDNF applied by injection into the eye (Sawai et al., 1996). Our finding that the application of BDNF in vivo does not lead to an increase in the mRNA levels of the growth-associated isotypes is surprising, because BDNF is able to enhance RGC neurite outgrowth in vitro (Cohen et al., 1994). In culture, however, the RGCs also are exposed to additional factors from serum or to growth-permissive 

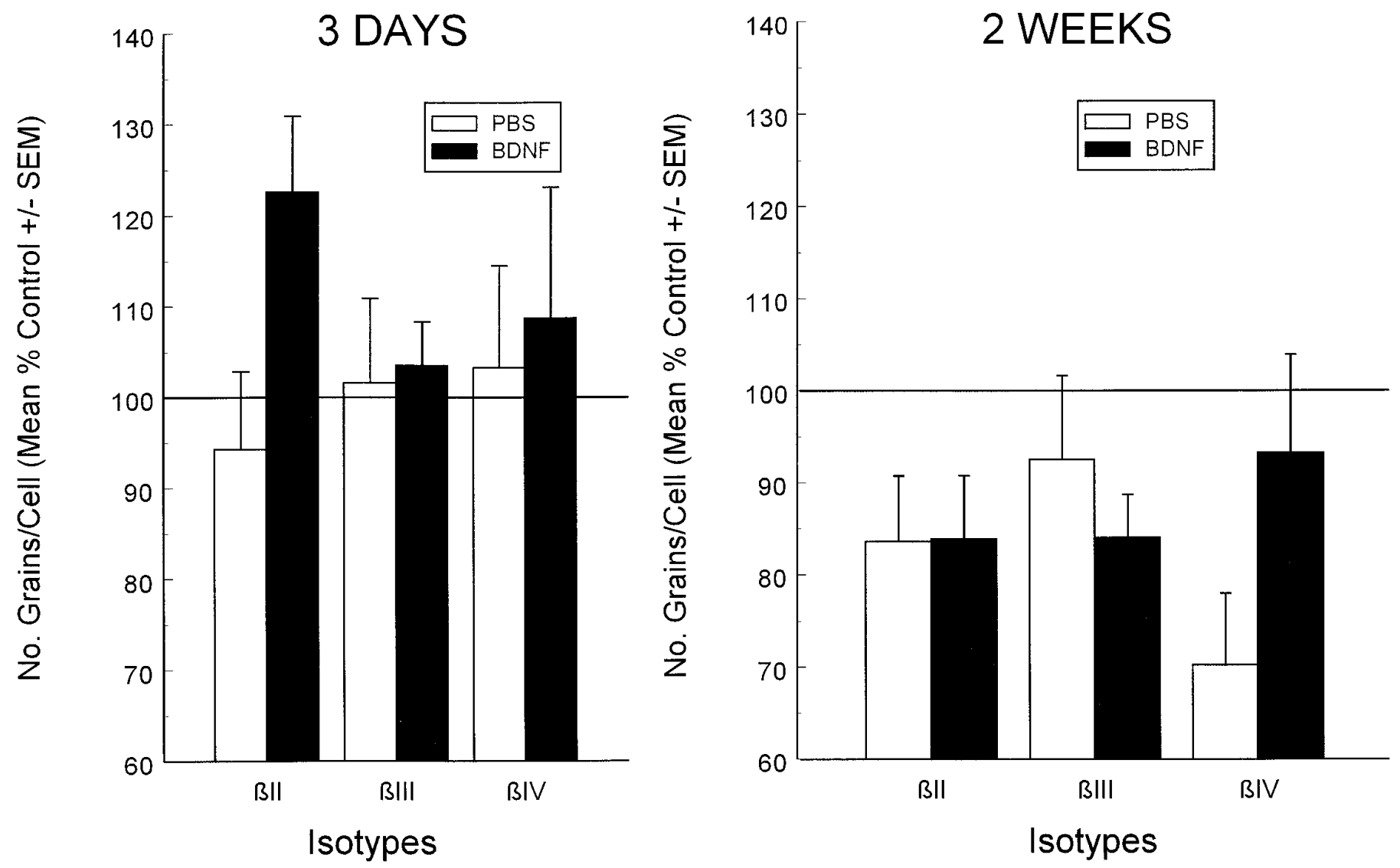

Figure 8. Tubulin isotype levels are not enhanced dramatically by BDNF application. Shown is the quantitation of tubulin isotype mRNA levels $3 \mathrm{~d}$ (left) or 2 weeks (right) after the application of BDNF to injured RGCs. BDNF elicited a modest enhancement of $\beta \mathrm{II}$ levels $3 \mathrm{~d}$ after treatment but did not affect the other tubulin isotypes. This effect was diminished by 2 weeks.

substrates, such as laminin or the surface of non-neuronal cells. We predict that in vivo the RGCs that regenerate are those for which the growth cones successfully interact with the peripheral nerve graft substrate.

Both in vitro experiments (Hopkins and Bunge, 1991) and experiments in which peripheral nerve grafts were freeze-thawed before being grafted into the visual system in rats (Berry et al., 1988) determined that living Schwann cells are essential for PN grafts to support regeneration. Although it is possible that the cells must be living to synthesize neurotrophic factors, the results reported here on BDNF application suggest that this is not their only role. We found that additional soluble factors released by the injection injury prevented the decrease in mRNA levels for tubulin isotypes but did not mimic the effects of the peripheral nerve graft on tubulin isotype expression. These results suggest that other diffusible factors likely to be produced by non-neuronal cells in PN grafts (Rappolee et al., 1988; Funakoshi et al., 1993; Elkabes et al., 1996) also may not be sufficient to increase mRNA levels of growth-associated tubulin isotypes. We speculate that the migration of Schwann cells into the optic nerve head where injured axons might contact their cell surface may provide critical substrate cues needed for regeneration.

\section{Cooperative signaling events may be required for successful regenerative growth}

Cell adhesion molecules present on Schwann cell surfaces, such as L1 and N-cadherin (Bixby et al., 1988; Kleitman et al., 1988a,b; Seilheimer and Schachner, 1988; Haussman et al., 1989) as well as extra- cellular matrix molecules (Bixby et al., 1988; Fawcett and Keynes, 1990), all may contribute to the growth-permissive environment of PN grafts. Recent studies suggest that there is convergence between neurotrophin and extracellular matrix-mediated intracellular signaling pathways (Clark and Brugge, 1995; Rozengurt, 1995), and perhaps neurotrophins and substrate molecules act in a cooperative manner to signal regenerative axon growth. Cooperative signaling may be needed to regulate intrinsic molecules, such as microtubules.

Although BDNF is not sufficient to elicit tubulin isotype switching in regeneration, it is also possible that growth-inhibitory molecules play a role (McKerracher and David, 1997). After axotomy RGC axons degenerate back toward their cell bodies, leaving their growth cones in the vicinity of the optic nerve head (Mansour-Robaey et al., 1994; Sawai et al., 1996). An intriguing possibility is that most RGCs attempt to regrow after neurite retraction but that their growth cones are diverted by the myelinderived inhibitory proteins (McKerracher and David, 1997) or by inhibitory molecules, such as chondroitin sulfate proteoglycan, at the optic nerve head (Geisert et al., 1992). Although the specific factors within the graft that affect tubulin isotype switching during regeneration are unknown, it is possible that growth-inhibitory molecules can repress the upregulation of growth-associated $\mathrm{mR}$ NAs that should follow injury.

\section{Specific regulation of individual tubulin isotypes}

The common downregulation of all isotypes after axotomy is likely to be regulated post-translationally by the soluble monomer pool of tubulin. An MREI sequence present in all of the $\beta$-tubulin 
isotypes (Lewis et al., 1985; Bachurski et al., 1994) is involved in detecting the monomer pool, and when monomers increase, isotype mRNA levels decrease (Cleveland et al., 1981). Therefore an increase in the tubulin monomer pool after axotomy would result in a decrease in all isotype mRNAs such as we report here. During regeneration of both RGCs and neurons of the peripheral nervous system, the soluble monomer pool of tubulin is likely to be depleted as new microtubules form to support the growing axon. Although this could account for a general upregulation in mRNA levels for all isotypes, the mechanism eliciting a selective increase in the expression of individual isotypes remains to be determined. Further, it is unclear why specific isotypes are recruited during both development and axonal regeneration. It has been hypothesized that the selective recruitment of individual isotypes for specific functions may be attributable to unique functional aspects of microtubules of varying isotype composition (Fulton and Simpson, 1976). The isotypes undergo unique post-translational modifications that modify tubulin properties and may affect their assembly characteristics and their ability to bind various microtubule-associated proteins (MAPs) (Serrano et al., 1984, 1985; Luduena et al., 1988; Luduena, 1993). Of particular interest, the $\beta$ III tubulin isotype, the expression levels of which increase during regeneration, is the only isotype to be phosphorylated at the unique C-terminal end (Diaz-Nido et al., 1990). This modification correlates with neurite extension in neuroblastoma cells (Gard and Kirschner et al., 1985), and phosphorylated tubulin is found primarily in the assembled microtubule fraction (DiazNido, 1990). Further, this phosphorylation of $\beta$ III tubulin at Serine 444 resides in a region important for MAP binding, and certain MAPs are know to favor process elongation (Leclerc et al., 1996). We speculate that the increased expression of the $\beta$ III isotype in regenerating axons reflects a requirement for a tubulin that can be modified by extracellular cues such as those that affect intracellular signal transduction mechanisms by protein phosphorylation.

\section{REFERENCES}

Bachurski CJ, Theodorakis NG, Coulson RMR, Cleveland DW (1994) An amino-terminal tetrapeptide specifies cotranslational degradation of $\beta$-tubulin but not $\alpha$-tubulin mRNAs. Mol Cell Biol 14:4076-4086.

Berry M, Hall S, Follows R, Rees L, Gregson N, Sievers J (1988) Response of axons and glia at the site of anastomosis between the optic nerve and cellular or acellular sciatic nerve grafts. J Neurocytol 17:727-744.

Bisby MA, Tetzlaff W (1992) Changes in cytoskeletal protein synthesis following axon injury and during axon regeneration. Mol Neurobiol 6:107-123.

Bixby JL, Lilien J, Reichardt LF (1988) Identification of the major proteins that promote neuronal process outgrowth on Schwann cells in vitro. J Cell Biol 107:353-361.

Chomczynski P, Sacchi N (1987) Single step method of RNA isolation by acid guanidinium thiocyanate-pheno-chloroform extraction. Anal Biochem 162:156-159.

Clark EA, Brugge JS (1995) Integrins and signal transduction pathways: the road taken. Science 268:233-238.

Cleveland DW, Lopata MA, Sherline P, Kirschner MW (1981) Unpolymerized tubulin modulates the level of tubulin mRNAs. Cell 25:537-546.

Cohen A, Bray GM, Aguayo AJ (1994) Neurotrophin-4/5 (NT-4/5) increases adult rat retinal ganglion cell survival and neurite outgrowth in vitro. J Neurobiol 25:953-959.

David S, Aguayo AJ (1981) Axonal elongation in peripheral nervous system "bridges" after central nervous system injury in adult rat. Science 214:391-393.

Diaz-Nido J, Serrano L, Lopez-Otin C, Vandekerckhove J, Avila J (1990) Phosphorylation of a neuronal-specific $\beta$-tubulin isotype. J Biol Chem 265:13949-13954.
Doster SK, Lozano AM, Aguayo AJ, Willard MB (1991) Expression of the growth-associated protein GAP-43 in adult rat retinal ganglion cells following axon injury. Neuron 6:635-647.

Elkabes S, DiCicco-Bloom EM, Black IB (1996) Brain microglia/macrophages express neurotrophins that selectively regulate microglial proliferation and function. J Neurosci 16:2508-2521.

Fawcett JW, Keynes RJ (1990) Peripheral nerve regeneration. Annu Rev Neurosci 13:43-60.

Fournier AE, McKerracher L (1995) Tubulin expression and axonal transport in injured and regenerating neurons in the adult mammalian central nervous system. Biochem Cell Biol 73:659-664.

Fournier AE, Beer J, Arregui C, Essagian C, Aguayo AJ, McKerracher L (1997) Brain-derived neurotrophic factor modulates GAP-43 but not $\mathrm{T} \alpha 1$ expression in injured retinal ganglion cells of adult rats. J Neurosci Res 47:561-572.

Fulton C, Simpson PA (1976) Selective synthesis and utilization of flagellar tubulin. The multi-tubulin hypothesis. In: Cell motility: Cold Spring Harbor conferences on cell proliferation (Goldman R, Pollard T, Rosenbaum J, eds), pp 987-1005. Cold Spring Harbor, NY: Cold Spring Harbor Laboratory.

Funakoshi H, Frisen J, Barbany G, Rimmusk T, Zachrisson O, Verge VMK, Persson H (1993) Differential expression of mRNAs for neurotrophins and their receptors after axotomy of the sciatic nerve. J Cell Biol 123:455-465.

Gard DL, Kirschner MW (1985) A polymer-dependent increase in phosphorylation of $\beta$-tubulin accompanies differentiation of a mouse neuroblastoma cell line. J Cell Biol 100:764-774.

Geisert EE, Williams RC, Bidanset DJ (1992) A CNS-specific proteoglycan associated with astrocytes in rat optic nerve. Brain Res 571:165-168.

Hausmann B, Sievers J, Hermanns J, Berry M (1989) Regeneration of axons from the adult rat optic nerve: influence of fetal brain grafts, laminin, and artificial basement membrane. J Comp Neurol 281:447-466.

Hoffman PN, Cleveland DW (1988) Neurofilament and tubulin expression recapitulates the developmental program during axonal regeneration: induction of a specific $\beta$-tubulin isotype. Proc Natl Acad Sci USA 85:4530-4533.

Hopkins JM, Bunge RP (1991) Regeneration of axons from adult rat retinal ganglion cells on cultured Schwann Cells is not dependent on basal lamina. Glia 4:46-55.

Jiang YQ, Oblinger MM (1992) Differential regulation of $\beta$ III and other tubulin genes during peripheral and central neuron development. J Cell Sci 103:643-651.

Johnson JE, Barde YA, Schwab M, Thoenen H (1986) Brain-derived neurotrophic factor supports the survival of cultured rat retinal ganglion cells. J Neurosci 6:3031-3038.

Kleitman N, Simon DK, Schachner M, Bunge RP (1988a) Growth of embryonic retinal neurites elicited by contact with Schwann cell surfaces is blocked by antibodies to L1. Exp Neurol 102:298-306.

Kleitman N, Wood P, Johnson MI, Bunge RP (1988b) Schwann cell surfaces but not extracellular matrix organized by Schwann cells support neurite outgrowth from embryonic rat retina. J Neurosci 8:653-663.

Leclerc N, Baas PW, Garner CC, Kosik KS (1996) Juvenile and mature MAP2 isoforms induce distinct patterns of process outgrowth. Mol Biol Cell 7:443-455.

Lewis SJ, Lee MG-S, Cowan NJ (1985) Five mouse tubulin isotypes and their regulated expression during development. J Cell Biol 101:852-861.

Luduena RF (1993) Are tubulin isotypes functionally significant? Mol Biol Cell 4:445-457.

Luduena RF, Zimmerman JH, Little M (1988) Identification of the phosphorylated $\beta$-tubulin isotype in differentiated neuroblastoma cells. FEBS Lett 230:142-146.

Mansour-Robaey S, Clarke DB, Wang Y-C, Bray GM, Aguayo AJ (1994) Effects of ocular injury and administration of brain-derived neurotrophic factor on survival and regrowth of axotomized retinal ganglion cells. Proc Natl Acad Sci USA 91:1632-1636.

McKerracher L, David S (1997) Role of MAG as an axon growth inhibitory protein for regeneration of injured neurons in the CNS. In: Fourth Altschul symposium. Cell biology and pathology of myelin: evolving biological concepts and therapeutic approaches, in press.

McKerracher L, Vidal-Sanz M, Aguayo AJ (1990) Slow transport rates of cytoskeletal proteins change during regeneration of axotomized retinal neurons in adult rats. J Neurosci 10:641-648.

McKerracher L, Essagian C, Aguayo AJ (1993a) Temporal changes in $\beta$-tubulin and neurofilament mRNA levels after transection of adult rat retinal ganglion cell axons in the optic nerve. J Neurosci 13:2617-2626. 
McKerracher L, Essagian C, Aguayo AJ (1993b) Marked increases in $\beta$-tubulin mRNA expression during regeneration of axotomized retinal ganglion cells in adult mammals. J Neurosci 13:5294-5300.

Mey J, Thanos S (1993) Intravitreal injections of neurotrophic factors support the survival of axotomized retinal ganglion cells in adult rats in vivo. Brain Res 602:304-317.

Miller FD, Naus CCG, Durand M, Bloom FE, Milner RJ (1987) Isotypes of $\alpha$-tubulin are differentially regulated during neuronal maturation. J Cell Biol 105:3065-3073.

Miller FD, Tetzlaff W, Bisby MA, Fawcett JW, Milner RJ (1989) Rapid induction of the major embryonic $\alpha$-tubulin mRNA, T $\alpha 1$, during nerve regeneration in adult rats. J Neurosci 9:1452-1463.

Moskowitz PF, Smith R, Pickett J, Frankfurter A, Oblinger MM (1993) Expression of the class III $\beta$-tubulin gene during axonal regeneration of rat dorsal root ganglion neurons. J Neurosci Res 34:129-134.

Rappolee DA, Mark D, Banda MJ, Werb A (1988) Wound macrophages express TGF-alpha and other growth factors in vivo: analysis by mRNA phenotyping. Science 241:708-712.

Rodriguez-Tebar A, Jeffrey PL, Thoenen H, Barde YA (1989) The survival of chick retinal ganglion cells in response to BDNF depends on their embryonic age. Dev Biol 136:296-303.

Rozengurt E (1995) Convergent signaling in the action of integrins, neuropeptides, growth factors, and oncogenes. Cancer Surveys 24:81-96.

Sawai H, Clarke DB, Kittlerova P, Bray GM, Aguayo AJ (1996) Brain-derived neurotrophic factor and NT-4/5 stimulate the growth of axonal branches from regenerating retinal ganglion cells. J Neurosci 16:3887-3894.

Seilheimer B, Schachner M (1988) Studies of adhesion molecules mediating interactions between cells of peripheral nervous system indicate a major role for L1 in mediating sensory neuron growth on Schwann cells in culture. J Cell Biol 107:341-351.

Serrano L, Avila J, Maccioni RB (1984) Controlled proteolysis of tubulin by subtilisin: localization of the site for MAP2 interaction. Biochemistry 23:4675-4681.

Serrano L, Montejo de Garcini E, Hernandez MA, Avila J (1985) Localization of the tubulin binding site for tau protein. Eur $\mathrm{J}$ Biochem 153:595-600.

Tetzlaff W, Alexander SW, Miller FD, Bisby MA (1991) Response of facial and rubrospinal neurons to axotomy: changes in mRNA expression for cytoskeletal proteins and GAP-43. J Neurosci 11:2528-2544.

Tetzlaff W, Kobayashi NR, Giehl KMG, Tsui BJ, Cassar SL, Bedard AM (1994) Response of rubrospinal and corticospinal neurons to injury and neurotrophins. Prog Brain Res 103:271-286.

Thanos S, Bahr M, Barde TA, Vanselow J (1989) Survival and axonal elongation of adult rat retinal ganglion cells: in vitro effects of lesion sciatic nerve and brain-derived neurotrophic factor. Eur J Neurosci $1: 19-26$.

Vidal-Sanz M, Bray GM, Villegas-Perez MP, Thanos S, Aguayo AJ (1987) Axonal regeneration and synapse formation in the superior colliculus by retinal ganglion cells in the adult retina. J Neurosci 7:2894-2909.

Vidal-Sanz M, Villegas-Perez MP, Bray GM, Aguayo AJ (1988) Persistent retrograde labeling of adult rat retinal ganglion cells with the carbocyanine dye DiI. Exp Neurol 102:92-101.

Villegas-Perez MP, Vidal-Sanz M, Rasminsky M, Bray GM, Aguayo AJ (1993) Rapid and protracted phases of retinal ganglion cell loss follow axotomy in the optic nerve of adult rats. J Neurobiol 24:23-36. 